\title{
Goods and services tax (GST) reforms and implementation: An economic analysis in the marine fisheries sector of Kerala, south India
}

\author{
SHYAM S. SALIM, HARSHA ELIZABETH JAMES AND MOHAMMED MEHAROOF \\ ICAR-Central Marine Fisheries Research Institute, Ernakulam North P. O., Kochi-682 018, Kerala, India \\ e-mail: shyam.icar@gmail.com
}

\begin{abstract}
Goods and services tax (GST), hailed as a historic tax reform, is a step taken by Government of India to improve transparency and accountability in the taxation system of our country. The fisheries sector is also expected to have a varied impact consequent to the introduction of these reforms. The present study assessed the level of awareness and perception of impact of GST and to estimate the additional cost per annum in marine capture fisheries sector of Kerala due to implementation of GST and also to highlight the possible positive effects of inclusion of diesel price under GST. The study was undertaken in the fish landing centers/harbours of Alappuzha and Ernakulam districts of Kerala, south India aimed at measuring the extent of uncertainty generated by introduction of GST. The study revealed that the implementation came as a complete bolt from the blue with majority of the fishers in disagreement with the process of implementation of GST without taking all stakeholders into confidence. Compared to value added tax (VAT), the GST and post-Guwahati Council GST rates are found to be high, affecting the fishing community at multidimensional levels. The results revealed that the marine capture fishing operations across all sectors in Kerala will be incurring an additional cost of ₹171.25 million per year due to GST introduction. However introducing GST on fuels will lead to a reduction of diesel price by $30-40 \%$ and $25-30 \%$ at 18 and $28 \%$ GST slabs respectively, which would reduce the ever increasing cost of fishing. The study also advocates that the implementation of GST in fuel prices should not add to overexploitation of the already dwindling fisheries resources.
\end{abstract}

Keywords: Fishermen, Goods and services tax (GST), Harbour, Livelihood, Tax

\section{Introduction}

Taxation system had been prevalent from time immemorial, originated from Egyptian dynasty to a predominant corvee and tithe (David, 2004) and now the value added tax (VAT) followed by goods and services tax (GST). Different countries have different taxation systems and more than 140 countries have implemented VAT / GST. France is the first country to introduce GST in 1954 which was very early compared to India (Kour et al., 2016). Goods and services tax, a historic tax reform, which came into effect from $1^{\text {st }}$ July, 2017 in India is a comprehensive, multi-stage, destination-based tax that will be levied on every value addition. In simple words, GST is an indirect tax levied on the supply of goods and services. GST law has replaced many indirect taxes like central excise duty, services tax, additional customs duty, surcharges and state-level value added tax that previously existed in India and will be administered together by the Centre and States (Chandra and Panwar, 2018). The GST regime operates across five tax slabs which include $0,5,12,18$ and $28 \%$. Under the GST regime, tax will be levied at every point of sale. Before GST, tax on tax was calculated and tax was paid by every purchaser including the final consumer. The taxation on tax often termed as the cascading effect of taxes is avoided in the GST taxation process.

Fisheries sector provides livelihoods and subsistence to fisher community and always attracted the attention and consideration of the government. Considering it as a main livelihood option, fish, fish products and fishing inputs were exempt from commercial taxes by almost all coastal states in India. However, over the years, the modernisation of fishing paved the way for introduction of new fishing technologies and taxes were also introduced on boats and engines. The other items were always outside the regime of commercial taxes. The Non-Governmental and community based organisations (NGOs and CBOs) and co-operatives working in the sector also enjoyed exemption of taxes in the supply of fishing inputs. When the VAT was introduced in 2005, no new taxes were introduced but the tax rates were marginally increased on taxable items. These exemptions helped the 14 million fishery dependent (directly or indirectly) individuals to meet their livelihood expenses.

The marine fisheries sector already grappling with constraints including rising fuel prices, dwindling fish stocks, exploitation by middlemen, climate change, 
reduced catch per unit effort (CPUE) and lower landings, now face a new challenge of further increase in operational costs due to GST introduction. Impact of GST on Indian agricultural and fisheries sectors were reported by various authors (Sheetal et al.. 2016; Vandna and Anil, 2017; Kumar, 2017; Ramya, 2017; Nandakumar, 2017). According to Vandna and Anil (2017), the changes in taxes due to introduction of GST in the fisheries sector would result in inclusion of the existing non-taxable items such as fish products, fishing equipment like nets, hooks and ropes under taxable category, as well as including some of the items under the highest category of $28 \%$ tax. Fishing hooks, fishing rods, fishing tackles and fishing twines are taxable at $12 \%$ under GST while that on fishing ropes has been fixed at $18 \%$. All these fishing gear were exempt from tax under the VAT regime. The GST rate for fishing vessels has been fixed at $5 \%$ and the same rate was levied under VAT. Outboard motors and ice boxes that had a VAT rate of $14.5 \%$ now attract a GST of $28 \%$ and $18 \%$ respectively. The GST rates introduced in the marine fisheries sector have increased the cost of the fishing implements and thereby reducing the income of fishermen. There is no denying the fact that the fishermen spend a major portion of income annually for replacement of fishing inputs and the levying of new taxes at very high rate will take away a major portion of his income as taxes (Sheetal et al., 2016). In this context, a study was conducted in Kerala State to assess the level of awareness and perception of impact of GST and to estimate the additional cost per annum in marine capture fisheries sector of Kerala due to GST

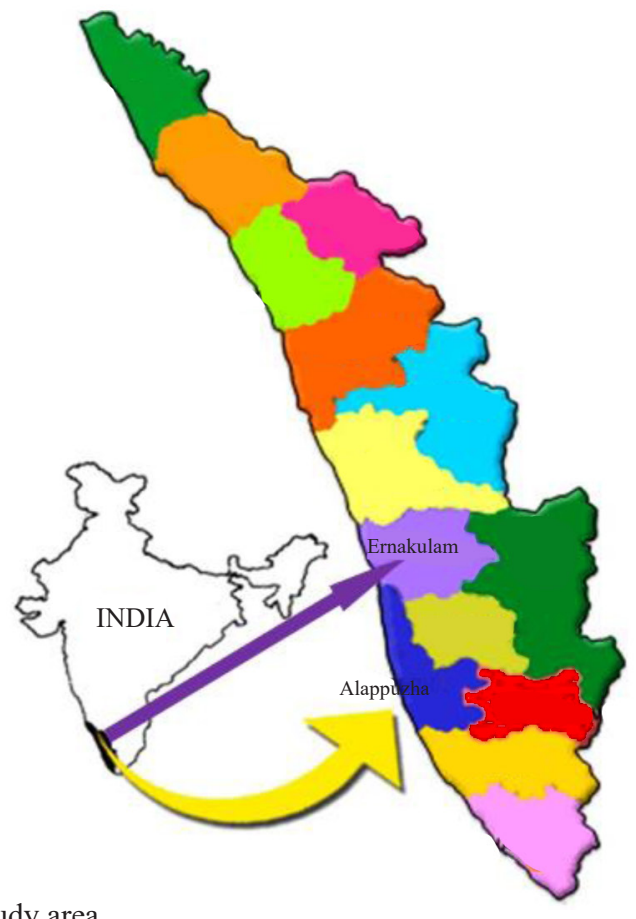

Fig.1. Study area implementation. The study also highlights the possible positive effects of inclusion of diesel price under GST.

\section{Materials and methods}

\section{Selection of study area}

The survey was conducted in fishing harbours of Alappuzha and Ernakulam coastal districts in Kerala, south India. In Alappuzha District, Thottapally Fishing Harbour was the selected study area. In Ernakulam, Munambam, Thoppumpadi and Kalamukku fishing harbours/landing centres were selected for the study.

\section{Data collection and methodology}

A pre-tested interview schedule was used for the collection of information on targeted variables directly from the fishermen through personal discussions and interviews. A total sample of 90 respondents was selected from the coastal districts of Alappuzha and Ernakulam by applying random sampling method. Data on socioeconomic and demographic profile of the respondents, level of awareness of fisherfolk about GST, fishers' perception on the impacts of GST on resources and resource users as well as sources of information on GST were collected from the selected respondents. The cost structure of the different fishing inputs were collected from the fishers and related organisations like Matsyafed net factory and Fisheries departments. Standard statistical analysis tools were used for data analysis. Annual depreciation was

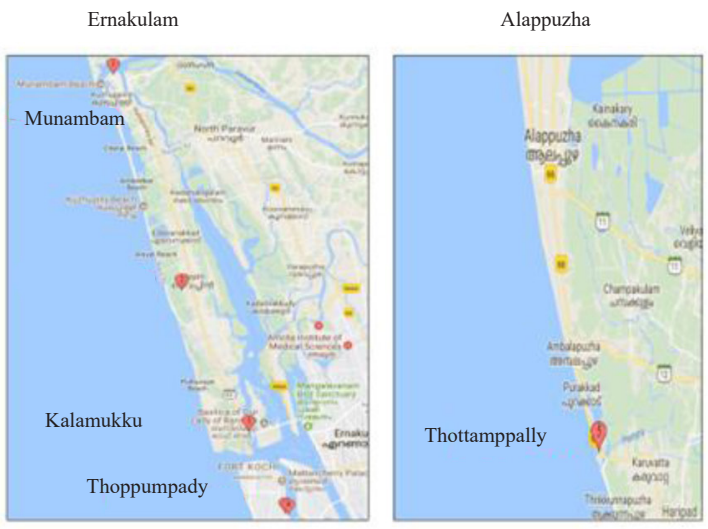


calculated using straight-line method for analysing and estimating the fixed cost of fishing units per annum.

Annual depreciation $=($ Asset cost - Residual value $) /$ Useful life of the asset

The change in the cost of fishing units due to alteration in the taxation system from VAT to GST and revised GST was calculated to estimate increase in cost of fishing per annum and additional cost per annum in marine capture fisheries sector. The possible effect of inclusion of diesel in the GST bracket was also calculated.

The total ice requirement is estimated at 1.3 million $\mathrm{t}$ which is two and half times the fish landings in Kerala during 2018. The requirements of plastic crates is based upon the average daily fish landings estimated at $2100 \mathrm{t}$ and a total of 50,000 crates with life of 3 years is required.

The possible positive effect of inclusion of diesel under GST was estimated based on assessing the international price of crude oil with ocean freight as on $3^{\text {rd }}$ February 2018. The different transaction costs, commission and taxes across entry, refinery, processing, landing cost and other operational cost along with margins were used for computing the final retail price.

Table 1. Respondents' profile

\begin{tabular}{ll}
\hline Parameters & Frequency \\
\hline Age (years) & \\
$<35$ & $12(13.33)$ \\
$35-45$ & $26(28.88)$ \\
$46-55$ & $26(28.88)$ \\
$56-65$ & $23(25.55)$ \\
$>65$ & $3(3.33)$ \\
\hline Category of respondents & \\
Fishermen & $68(75.55)$ \\
Boat owner & $13(14.44)$ \\
Fish vendor & $2(2.22)$ \\
Fish processor & $7(7.77)$ \\
Others & $0(0.00)$ \\
\hline Experience in fishing (years) & \\
$<10$ & $5(5.55)$ \\
10 to 25 & $54(60.00)$ \\
$>25$ & $31(34.44)$ \\
\hline
\end{tabular}

\section{Results and discussion}

Respondent profile

The respondent profile including socio-economic details related to their age, occupation and experience in fishing is furnished in Table 1.

Majority (28.88\% each) of the respondents belonged to two categories of age groups of $35-45$ and 46-55 followed by $25 \%$ belonging to the $56-65$ category. Greater part $(75 \%)$ of the respondents surveyed were fishermen followed by boat owners (14\%) and fish processors (7.7\%). Sixty percent of the respondents have a fishing experience of $10-25$ years followed by $34 \%$ having greater than 25 years of experience and 5\% having less than 10 years of experience. A vast majority (87\%) of the respondents uses mechanised boats for fishing operations and only $3 \%$ of them use traditional boats reflecting the general trend in the marine fisheries sector, with greater part of the landings and effort captured by mechanised sector from the traditional sector in a phased manner, beginning in the late fifties by the Indo-Norwegian Project. On an average, the respondents go for 4 fishing trips a week. The respondent profile indicated that fishing is still a prominent livelihood option for the fishers with around $59 \%$ of them having no other alternative livelihood options (ALOs). Forty one of them reported to have some other livelihood option other than fishing but the huge dependence of them on fishing for meeting their livelihood expenses is reflected in 55\% of them deriving more than $75 \%$ of their income from fishing followed by 30 and 14\% deriving $51-75 \%$ and $25-50 \%$ of their income respectively, from fishing.

Awareness and perception about taxes and introduction of GST in fisheries sector

It was not surprising to note that all the respondents have heard about taxes, but only to an apparent level. Existence of taxes in fisheries sector is known to $60 \%$ of the respondents while $33 \%$ were completely unaware of the same. Lack of knowledge about existing taxation system among the respondents, even if only a minority, point towards the need of more robust information dissemination mechanisms. It is under such circumstances of existing gaps in creating awareness about our current taxation system that GST was introduced. The GST was not too unknown to them in general, but its implications in fisheries sector was recognised by only $33.33 \%$. Media $(42 \%)$ was the main source through which the fishers came to know about GST followed by friends (41.34\%) and relatives $(17 \%)$. It was disquieting to hear from a vast majority $(87.7 \%)$ of the respondents that no government body has come forward and explained to them about GST and its implications. The lukewarm initiatives from the part of government agencies to create awareness about their revolutionary reform and sensitise the fishermen concerning its implications, will definitely affect its rate of adoption.

Impact of GST in fishing industry was felt by $89 \%$ of the fishers with $54 \%$ opining that it would affect fishermen the most, followed by boat owners $(30.71 \%)$, consumers $(8.57 \%)$ and fish vendors $(7 \%)$. This shows the surging 
effect of GST introduction, touching top level producers to the lower level consumers. The fishers reasoned that GST rates introduced in the fisheries sector inputs have increased the cost of the fishing implements, which will lead to reduced fishing efforts and thereby reduced income.

Another interesting finding of the study is that even though most of the respondents were unaware about the implications of GST in fisheries sector, $43 \%$ of them strongly agreed that introduction of GST on fuels is going to have an affirmative effect on fishing. ICFA (2017) study indicated that $60 \%$ of the respondents epitomised a positive notion on the Indian agricultural sectors, however $27 \%$ of the responses were towards the negative side. But in the current study, the responses on positive and negative impact of GST on marine fisheries sector were noted to be vice-versa.

Changes in the cost structure of fishing equipments and inputs

The changes in the cost structure of the different fishing inputs were assessed by collecting information on the prices from Matsyafed, fisheries departments and fishing harbours. It was found that fishing rods, fishing tackles and fishing twines are taxable at $12 \%$ under GST while that on fishing rope and hooks has been fixed at $5 \%$. All these fishing gear were exempt from tax under the VAT regime. GST on nylon twine used for net is now taxed at $18 \%$ and floats used for nets now attract $28 \%$ tax. Outboard motors and ice boxes that had a VAT rate of $14.5 \%$ now attract a GST of 28 and $18 \%$ respectively. The tax rate of existing taxable items was increased and some of the items like marine engines were included in the highest category of $28 \%$ tax. Ice, which is an inevitable input in fisheries sector, now attracts 5\% tax. Similarly, Singh et al. (2018) reported the impact of $12 \%$ GST on agriculture equipment. The study also discussed the impact of GST on fishery sector with $12 \%$ taxable charges for fishing hooks, rods, tackles and twines and $18 \%$ tax charges for fishing ropes. Likewise, Agarwal et al. (2017) studied the short term impact of GST and its reflections in small and medium businesses across Uttarakhand and Kerala states. The study also reported the different rate taxonomies of goods and services. The tax slabs of fishing inputs before and after GST introduction are given in Table 2.

\section{Increase in cost of fishing per annum}

GST was introduced on $1^{\text {st }}$ July 2017 as one of the most important financial reform in India after the 90's. Amid subsequent ruckus about its introduction and call for its withdrawal, $23^{\text {rd }}$ Guwahati GST Council meeting was held on 10 November 2017 and the rates were revised. Tax slabs were reduced for some of the products, which are expected to help fishermen tide over the GST shock (MoF, 2017).

Data of inputs used in different sectors (mechanised, motorised and non-motorised), their basic prices, quantity used and life was collected and the cost of each input per annum was calculated based on the average number of trips operated per year during VAT regime, after GST

Table 2. Taxation of fishing equipments/inputs before and after GST introduction (\%)

\begin{tabular}{lllll}
\hline Particulars & Fishing equipments/Inputs & VAT & GST (1 July 2017) & $\begin{array}{l}\text { Post 23rd GST council meeting* } \\
(10 \text { Nov. 2017) }\end{array}$ \\
\hline Fishing Inputs/equipments & Outboard motor & 14.5 & 28 & 28 \\
& Ice boxes & 14.5 & 18 & 18 \\
& Plastic crates & 5 & 18 & 18 \\
& Spare parts & $5 \& 14.5$ & 28 & 12 \\
& Ice & 0 & 5 & 5 \\
& Fishing hooks & 0 & 12 & 5 \\
& Fishing rods & 0 & 12 & 12 \\
& Fishing ropes & 0 & 12 & 5 \\
& Fishing nets & 0 & 12 & 5 \\
& Fishing twines & 0 & 12 & 12 \\
\hline Navigational equipments & Compasses & 14.5 & 28 & 18 \\
& Direction finding compasses & 14.5 & 28 & 18 \\
& Navigational instruments & 14.5 & 28 & 18 \\
\hline Sea safety devices & Radio navigational aid apparatus & 14.5 & 28 & 5 \\
& Life jackets & 5 & 12 & 5 \\
& Life buoy & 5 & 12 & 18 \\
\hline${ }^{*}$ Considering the unpleasant effect of the higher tax burden in fisheries, Government had revised the taxes on these products 0 10 November 2017
\end{tabular}

${ }^{*}$ Considering the unpleasant effect of the higher tax burden in fisheries, Government had revised the taxes on these products on 10 November 2017 
introduction and its revision. The taxes on fishing vessels remain as a status quo at $5 \%$. On the output front, the sudden increase of GST on outboard motors and ice boxes from 14.5 to $28 \%$ and $18 \%$ respectively was a shock to the fishermen due to the additional cost on inputs (Singh et al., 2018).

The annual cost of fishing equipments and inputs in each sector during different tax regimes is furnished in Tables 3-7.

Table 3. Annual cost of fishing equipments and inputs for trawlers and gillnetters

\begin{tabular}{llllll}
\hline \multirow{2}{*}{ Item } & Basic price (₹) & Life & & \multicolumn{2}{c}{ Annual costs } \\
\cline { 5 - 6 } & & & VAT (₹) & GST (₹) & Post 23 $3^{\text {rd }}$ GST council (₹) \\
\hline Engine & $12,50,000$ & 30 & 47,708 & 53,333 & 53,333 \\
Gear/Net (per kg) & 600 & 5 & 24,000 & 26,880 & 25,200 \\
Fishing rope - Type A (per kg) & 250 & 3 & 7,833 & 8,773 & 8,225 \\
Fishing rope - Type B (per kg) & 250 & 3 & 17,167 & 19,227 & 18,025 \\
Twine (per kg) & 250 & 1 & 11,250 & 12,600 & 12,600 \\
Plastic crates & 300 & 3 & 552 & 620 & 620 \\
Fuel can & 100 & 3 & 166 & 187 & 187 \\
Floaters & 30 & 3 & 2,835 & 3,456 & 3,456 \\
Sinkers (per kg) & 250 & 3 & 13,125 & 16,000 & 14,750 \\
Fish sweeper & 30 & 0.5 & 105 & 118 & 118 \\
Life jackets & 1,000 & 3 & 1,768 & 1,885 & 1,768 \\
Life buoy & 1,500 & 3 & 1,657 & 1,767 & 1,657 \\
Fire extinguisher & 600 & 1 & 687 & 768 & 708 \\
Lantern & 750 & 2 & 394 & 480 & 443 \\
Water pump & 1,700 & 5 & 361 & 385 & 385 \\
GPS & 24000 & 5 & 5,496 & 6,144 & 5,664 \\
Echosounder & 30,000 & 5 & 6,870 & 7,680 & 7,080 \\
VHF radio & 10,000 & 5 & 2,196 & 2,455 & 2,263 \\
Lubricant oil & 200 & - & 82,440 & 84,960 & 84,960 \\
\hline Total & & $2,26,610$ & $2,47,719$ & $2,41,442$ \\
\hline
\end{tabular}

Table 4. Annual cost of fishing equipments and inputs for ring seiners and purse seiners

\begin{tabular}{|c|c|c|c|c|c|}
\hline \multirow{2}{*}{ Item } & \multirow{2}{*}{ Basic price (₹) } & \multirow{2}{*}{ Life } & \multicolumn{3}{|c|}{ Annual costs } \\
\hline & & & VAT (₹) & GST (₹) & Post $23^{\text {rd }}$ GST council (₹) \\
\hline Engine & $18,50,000$ & 30 & 70,608 & 78,933 & 78,933 \\
\hline Gear/Net (per kg) & 600 & 2 & 660,000 & $7,39,200$ & $6,93,000$ \\
\hline Fishing rope - Type A (per kg) & 250 & 3 & 94,000 & $1,05,280$ & 98,700 \\
\hline Fishing rope - Type B (per kg) & 250 & 3 & 20,600 & 23,072 & 21,630 \\
\hline Twine (per kg) & 250 & 1 & 67,500 & 75,600 & 75,600 \\
\hline Plastic crates & 300 & 3 & 552 & 620 & 620 \\
\hline Fuel can & 100 & 3 & 133 & 149 & 149 \\
\hline Floaters & 30 & 3 & 80,325 & 97,920 & 97,920 \\
\hline Sinkers (per kg) & 250 & 3 & $1,05,000$ & 128,000 & 118,000 \\
\hline Fish sweeper & 30 & 1 & 53 & 59 & 59 \\
\hline Life jackets & 1,000 & 3 & 7,070 & 7,541 & 7,070 \\
\hline Life bouy & 1,500 & 3 & 1,657 & 1,767 & 1,657 \\
\hline Fire extinguisher & 600 & 1 & 687 & 768 & 708 \\
\hline Lantern & 750 & 2 & 394 & 480 & 443 \\
\hline Water pump & 1,700 & 5 & 361 & 385 & 385 \\
\hline GPS & 24,000 & 5 & 5,496 & 6,144 & 5,664 \\
\hline Echo sounder & 30,000 & 5 & 6,870 & 7,680 & 7,080 \\
\hline VHF radio & 10,000 & 5 & 2,196 & 2,455 & 2,263 \\
\hline Lubricant oil & 200 & - & 146,560 & $1,51,040$ & $1,51,040$ \\
\hline Total & & & $12,70,061$ & $14,27,095$ & $13,60,922$ \\
\hline
\end{tabular}


Table 5. Annual cost of fishing equipments and inputs for long liners

\begin{tabular}{llllll}
\hline Item & Basic price (₹) & Life & & \multicolumn{2}{c}{ Annual costs } \\
\cline { 5 - 6 } & & & VAT (₹) & GST (₹) & Post 23 ${ }^{\text {rd }}$ GST council (₹) \\
\hline Engine & $12,50,000$ & 25 & 57250 & 64000 & 64000 \\
Fishing rope (per kg) & 250 & 2 & 7725 & 8652 & 8111 \\
Nylon monofilament (per meter) & 10 & 1 & 320000 & 358400 & 358400 \\
Fishing hook (for 100 pc) & 100 & 1 & 1,152 & 1290 & 1,210 \\
Fishing rod & 850 & 1 & 4,150 & 4,648 & 4,648 \\
Plastic crates & 300 & 3 & 207 & 232 & 232 \\
Insulated boxes & 4,000 & 2 & 4,351 & 4,484 & 4,484 \\
Fuel can & 100 & 3 & 2,328 & 2,616 & 2,616 \\
Floaters - Type A & 1,500 & 1 & 4,167 & 5080 & 5,080 \\
Floaters - Type B & 40 & 3 & 1,295 & 1,579 & 1,579 \\
Sinkers & 60 & 1 & 37,800 & 46,080 & 42,480 \\
Fish sweeper & 30 & 1 & 53 & 59 & 59 \\
Life jackets & 1,000 & 3 & 1,768 & 1,885 & 1,768 \\
Life buoy & 1,500 & 3 & 1,105 & 1,178 & 1,105 \\
Fire extinguisher & 600 & 1 & 687 & 768 & 708 \\
Lantern & 750 & 2 & 394 & 480 & 443 \\
GPS & 24,000 & 5 & 15 & 6,144 & 5,664 \\
Echo sounder & 30,000 & 5 & 15 & 28 & 7,080 \\
VHF radio & 10,000 & 5 & 15 & 28 & 18 \\
Lubricant oil & 200 & - & 15 & 18 & 18 \\
\hline Total & & & $5,41,432$ & $6,02,671$ & $5,96,889$ \\
\hline
\end{tabular}

Table 6. Annual cost of fishing equipments and inputs for motorised sector

\begin{tabular}{|c|c|c|c|c|c|}
\hline \multirow{2}{*}{ Item } & \multirow{2}{*}{ Basic price (₹) } & \multirow{2}{*}{ Life } & \multicolumn{3}{|c|}{ Annual costs } \\
\hline & & & VAT(₹) & GST(₹) & Post $23^{\text {rd }}$ GST council (₹) \\
\hline Outboard motor & 90,000 & 4 & 25,763 & 28800 & 28,800 \\
\hline Gear/Net (per kg) & 600 & 8 & 1,875 & 2100 & 1,969 \\
\hline Fishing rope (per kg) & 250 & 2 & 515 & 577 & 541 \\
\hline Twine (per kg) & 250 & 2 & 563 & 664 & 630 \\
\hline Plastic crates & 300 & 3 & 345 & 387 & 387 \\
\hline Insulated boxes & 40,000 & 2 & 4,351 & 4484 & 4,484 \\
\hline Fuel can & 100 & 2 & 150 & 168 & 168 \\
\hline Floaters & 10 & 3 & 280 & 341 & 341 \\
\hline Sinkers (per kg) & 250 & 3 & 1,313 & 1600 & 1,475 \\
\hline Fish sweeper & 30 & 1 & 26 & 30 & 30 \\
\hline Life jackets & 1,000 & 3 & 1,061 & 1131 & 1061 \\
\hline Life bouy & 1,500 & 3 & 1,105 & 1178 & 1,105 \\
\hline Lantern & 750 & 2 & 394 & 480 & 443 \\
\hline GPS & 13,000 & 5 & 2,874 & 3213 & 2,962 \\
\hline Lubricant oil & 200 & - & 29,312 & 30208 & 30,208 \\
\hline Total & & & 69,924 & 75,361 & 74,602 \\
\hline
\end{tabular}

Introduction of GST has many implications in fisheries sector, but increase in cost of fishing per annum can be used as comprehensive expression of its effect. Analysis of data related to the fixed cost of fishing equipment revealed that the introduction of GST has its effects in mechanised, motorised and traditional sectors, with an additional annual increase in cost of fishing by 8.2 ,
6.69 and $9.22 \%$ respectively in each sector. A comparison of the increase in the cost of fishing before and after revising GST rates is given in Table 8 .

Additional cost per annum in marine capture fisheries sector

Marine capture fisheries play a vital role in Kerala's economy, providing employment and income to around 
Table 7. Annual cost of fishing equipments and inputs for non-motorised sector

\begin{tabular}{llllll}
\hline \multirow{2}{*}{ Item } & Basic price $(₹)$ & \multirow{2}{*}{ Life } & & \multicolumn{2}{c}{ Annual costs } \\
\cline { 5 - 6 } & & & VAT (₹) & GST $(₹)$ & Post 23 $3^{\text {rd }}$ GST council (₹) \\
\hline Gear/Net (per kg) & 600 & 10 & 720 & 806 & 756 \\
Fishing rope (per kg) & 250 & 2 & 309 & 346 & 324 \\
Twine (per kg) & 250 & 2 & 1,125 & 1,328 & 1,260 \\
Fishing hook (for 100 pc) & 100 & 0.5 & 192 & 215 & 202 \\
Fishing rod & 850 & 1 & 1,660 & 1,859 & 1,859 \\
Plastic crates & 300 & 3 & 138 & 155 & 155 \\
Floaters & 10 & 3 & 224 & 273 & 273 \\
Sinkers (per kg) & 250 & 3 & 875 & 1067 & 983 \\
Fish sweeper & 30 & 1 & 26 & 30 & 30 \\
Life Jacket & 1,000 & 2 & 707 & 754 & 707 \\
Torch & 300 & & 158 & 192 & 177 \\
\hline Total & & 6134 & 7025 & 6726 \\
\hline
\end{tabular}

Table 8. Additional increase in the cost of fishing per annum

\begin{tabular}{lll}
\hline Fishing crafts & $\begin{array}{l}\text { GST } \\
(\%)\end{array}$ & $\begin{array}{l}\text { Post 23 } \\
(\%)\end{array}$ \\
\hline Trawlers and gillnetters & 9.78 & 6.59 \\
Purse seiners and ring seiners & 12.50 & 7.80 \\
Liners & 11.30 & 10.21 \\
Total mechanised & 11.19 & 8.20 \\
Motorised & 7.78 & 6.69 \\
Non-motorised & 14.96 & 9.22 \\
\hline
\end{tabular}

6 lakh marginalised fishermen. With most of the fishermen entirely dependent on the fishing income for their livelihood, any alteration in relation to it is going to affect the entire community from its root. Tharani and Ahmed (2017), stated the merits and demerits of GST on agriculture produces; machineries, research and information on the government policies, schemes, agriculture loans, market prices, animal husbandary, fisheries, horticulture, loans/ credit and sericulture. The study articulates that the system is often difficult to implement such tax by the centre for an agro-commodity due to the nature of trivial policies adopted by the different states. However, the centre has implemented them to make the tax support policies efficient thereby covering pressure on the people.

Results of the present study show that, marine capture fisheries sector in Kerala will be incurring an additional cost of ₹171.25 million per year with ₹116.76 million in mechanised, ₹52.28 million in motorised and ₹2.19 million in traditional sectors respectively. Ice which was earlier exempt from tax, now attracts 5\% GST and plastic crates used for ice storage and transportation are now charged $18 \%$ tax, which will lead to total additional cost of ₹5.7 million. Comparison of the increase in the cost of fishing before and after revising GST rates at the $23^{\text {rd }}$ Guwahati GST Council meeting is given in Table 9.

Possible positive effects of inclusion of diesel under GST

Most of the fishermen are not aware about the technicalities or the phased GST mechanisms because of which their initial opinion on GST was negative. Nowadays diesel prices are determined on daily basis in India with allegation on oil companies exercising huge profit; the important note is that the price of diesel is consistently showing an increasing trend. This increase

Table 9. Additional cost per annum incurred in marine capture fisheries of Kerala

\begin{tabular}{llllll}
\hline Sectors & Number of crafts & $\begin{array}{l}\text { GST }(₹) \\
(01-07-17)\end{array}$ & $\begin{array}{l}\text { Post 23 } \\
(10-11-17)\end{array}$ & $\begin{array}{l}\text { Total additional cost in } \\
\text { GST (₹ million) }\end{array}$ & $\begin{array}{l}\text { Total additional cost in Post 23 } \\
\text { GST (₹ million) }\end{array}$ \\
\hline Mechanised & 4722 & 202251.47 & 144365.26 & 177.37 & 116.76 \\
Motorised & 11175 & 5437.28 & 4678.39 & 60.76 & 52.28 \\
Traditional & 5884 & 604.56 & 372.64 & 3.57 & 2.19 \\
\hline Total & & & 241.70 & 171.23 \\
Input costs & & & & \\
Ice & 91.52 & 96.10 & 4.57 & 4.57 & \\
Plastic crates & 9.10 & 10.22 & 1.12 & 1.12 & 5.70 \\
\hline Total & & & 5.70 &
\end{tabular}


in prices despite decrease in international crude oil prices is due to the non-evasion of excise duty and VAT charged by the Government of India and the State Governments respectively. In case of diesel which is commonly used in fishing sector of Kerala, around $43 \%$ of the fuel price is constituted by these taxes. Increase in the price of diesel is believed to affect the fishers with reduction in fishing trips and increasing cost of fishing. But inclusion of GST on fuels may have a constructive effect on fisheries sector as the results say that introducing GST on fuels leads to a reduction of diesel price by 33 and $27 \%$ at 18 and $28 \%$ GST slabs respectively (Table 10). This, in turn, will dwindling catches and lower landings. currently faced by the dependents of fisheries sector. The immediate increase in cost of fishing equipments (fixed cost) due to GST is likely to get balanced if GST is introduced for fuels too, as $65 \%$ of the operating cost in fishing is contributed by fuels and inclusion of fuel in GST will reduce the price by $30-40 \%$, so that the fishers will go for more deep sea fishing and can exploit more deep sea resources. As fisheries is one of the major sectors contributing to the Indian economy, it is expected that the Government will reconsider its decision on GST in fisheries sector and keep a lower tax slab on fishing equipments in a phased manner and consider including fuel under GST.

Table 10. Price of diesel if included under GST

\begin{tabular}{llll}
\hline Price of diesel with GST (₹ per litre) & & Cost of diesel per trip ${ }^{*}(₹)$ & Cost reduction (\%) \\
\hline At $18 \%$ & 42.77 & 20572 & 32.66 \\
At $28 \%$ & 46.39 & 22314 & 26.95 \\
\hline Subsidised diesel price with GST for fishers & & & 32.66 \\
\hline At $18 \%$ & 39.35 & 18927 & 26.95 \\
At $28 \%$ & 42.68 & 20529 &
\end{tabular}

"Note: Average diesel usage/fishing trip: 450-500 1, calculated based on Vivekanandan et al. (2013)

benefit fishing by reducing the fishing cost, as $65 \%$ of the fishing cost is contributed by fuel.

It should be noted that according to the finding of the study, even though most of the respondents are unaware of the implications of GST in fisheries sector, $43 \%$ of them strongly agree that introduction of GST on fuels is going to have an affirmative effect on fishing. Inclusion of diesel under GST bracket can thus act as a balancing step, saving the fisherfolk from the undesirable effects of inclusion of previously tax exempted fishing inputs under higher GST tax slabs.

In general, it is expected that the technology driven fishing investment may take a back stage due to increasing taxes on navigational equipment brought by the introduction of GST. Considering the simmering tension generated by GST implementation in the country, the government is expected to reconsider its decision. In the $23^{\text {rd }}$ Guwahati GST Council meeting, Government has made some changes in the tax rates, which is expected to help the fisheries sector tide over the GST shock (MoF, 2017). Due to the higher tax burden, the total marine capture fisheries sector of Kerala will incur an additional cost of ₹171.23 million per annum which in turn would result in the increased price of marine fish in Kerala. Also the cost of fishing inputs in different sectors viz., mechanised, motorised and traditional will be increased by $8.22,6.69$ and $9.22 \%$ respectively, which will add on to the problems of reduced catch per unit effort (CPUE),

\section{Acknowledgments}

The authors are thankful to the Director, ICARCMFRI, Kochi for the support extended to carry out this work.

\section{References}

Aryan Agarwal, Richa Sekhani and Deepanshu Mohan 2017. Short-term impact of GST on small and medium businesses across India: reflections from case of local markets in Uttarakhand and Kerala. Centre for Economic Studies, India, p. 3-29.

Chandra, P. and Shradha Panwar 2018. GST-Indirect Tax Reform, Int. J. Res. in Appl. Sci. Eng. Tech., 6(2): 2275-2284.

David, F. Burg. 2004. A world history of tax rebellions. Taylor and Francis, UK, $532 \mathrm{pp}$.

ICFA 2017. Implication of GST on Agri-input market in India: Survey Report, Indian Council of Food and Agriculture, India, p. 1-11.

Kour, M., Kajal Chaudhary, Surjan Singh and Baljinder Kaur. 2016. A study on impact of GST after its implementation, Int. J. Innov. Stud. Sociol. Humanit., 1(2): 17-24.

MoF 2017. Recommendations on GST rate changes. $23^{\text {rd }}$ Meeting of GST Council, 10 November, 2017, Guwahati, Assam, India. Ministry of Finance, Government of India. http://pib.nic.in/newsite/PrintRelease aspx?relid=173406.

Nandakumar, T. 2017. Fishers fume at GST rates. The Hindu, 7 July 2017. https://www.thehindu.com/news/national/ kerala/fishers-fume-at-gst-rates-on-fishing gear/article 192 34602.ece 
Singh, N. P., Jaiprakash Bisen, Venkatesh, P. and Aditya, K. S. 2018. GST in India: reflections from food and agriculture, Agric. Econ. Res. Rev., 31 (2): 175-185. DOI: 10.5958/0974-0279.2018.00035.6.

Ramya, N. 2017. GST and its impact on various sectors. J. Manage. Sci., 2249-2260

Kumar, S. V. 2017. Kerala's fisheries sector in deep waters, post note-ban and GST. The Hindu, 20 November, 2017. https://www.thehindubusinessline.com/economy/ agri-business/keralas-fisheries-sector-in-deepwaters-post-noteban-and-gst/article9967607.ece.
Sheetal, C., Bhaumik, U. and Patra, B. C.2016. GST and its impact in agricultural and fishery products. Int. J. Curr. Res. Acad. Rev., 4(5): 84-100.

Tharani, S. and Saleem Ahmed 2017. Impact of Goods and Service tax in Agricultural Sector in India. Int. J. Tech. Res. Manage., 4(9): 1-6.

Vandna Sharma and Anil Sharma 2017. GST-A big fish to eat fisheries? https://taxguru.in/goods-and-service-tax/gstabig -fish-eat-fisheries.html.

Vivekanandan, E., Singh, V. V. and Kizhakudan Joe K. 2013. Carbon footprint by marine fishing boats of India. Curr. Sci., 105(3): 361-366. 